\title{
Peningkatan Kemampuan Belajar Mandiri pada Mata Kuliah Operasional Riset melalui Self Regulated Learning
}

\author{
Sri Rahmawati Fitriatien ${ }^{1 *}$, Ninik Mutianingsih ${ }^{2}$ \\ Program Studi Pendidikan Matematika, Universitas PGRI Adi Buana Surabaya \\ Jalan Ngagel Dadi III-B/37, Surabaya, Jawa Timur, Indonesia \\ 1rahmawatien.srf@unipasby.ac.id,2ninikmutia@unipasby.ac.id
}

Artikel diterima: 24-11-2019, direvisi: 25-01-2020, diterbitkan: 31-01-2020

\begin{abstract}
Abstrak
Penelitian ini dilatarbelakangi oleh kondisi mahasiswa yang masih kurang memiliki self concept dalam mempelajari mata kuliah operasional riset. Tujuan penelitian ini adalah mengetahui perkembangan kemampuan diri dalam menyelesaikan permasalahan sistem pengambilan keputusan yang dimiliki mahasiswa secara mandiri. Subjek penelitian sebanyak 49 mahasiswa Program Studi Pendidikan Matematika Universitas PGRI Adi Buana Surabaya, terdiri dari angkatan 2017-B dan 2017-C. Metode penelitian yaitu penelitian tindakan kelas yang difokuskan pada proses perbaikan pembelajaran secara mandiri melalui self regulated learning. Data kuantitatif diperoleh melalui tes tulis sedangkan data kualitatif diperoleh melalui observasi dan wawancara. Analisis data penelitian ini menggunakan perhitungan persentase nilai rata-rata dengan batasan persentase nilai rata-rata minimal 75\% maka pelaksanaan proses perbaikan dapat dihentikan. Temuan dari hasil penelitian ini menunjukkan bahwa proses perbaikan pembelajaran melalui self regulated learning mampu mengarahkan mahasiswa untuk belajar mandiri secara aktif dan memberikan motivasi dalam berkompetisi secara positif sehingga memperoleh hasil capaian pembelajaran yang lebih baik.

Kata Kunci: motivasi belajar, prestasi akademik, self regulated learning.
\end{abstract}

\section{Fostering Self Directed Learning Ability on The Subject of Operational Research Through Self Regulated Learning}

\begin{abstract}
This research is motivated by the condition of students who still lack self-concept in studying operational research subjects. The purpose of this study is to determine the development of the ability to self in solving the problem of decision-making systems that are owned by students independently. This study was implemented at the University of PGRI Adi Buana Surabaya, participated by 49 undergraduate students majoring in Mathematics Education, 2017-B and 2017-C. The research method used is classroom action research focused on the process of improving learning independently through self-regulated learning. Quantitative data were obtained through written tests while qualitative data were obtained through observation and interviews. Analysis of the data used in this study using the calculation of the percentage of the average value with a limit of the average percentage value of at least $75 \%$, then the implementation of the improvement process can be stopped. The finding of this study indicates that the learning improvement process through self-regulated learning can direct the students to actively self learn and motivate them to compete positively to obtain a better learning outcome. Keywords: learning motivation, academic achievement, self-regulated learning.
\end{abstract}




\section{Pendahuluan}

Operasional riset merupakan salah satu mata kuliah wajib untuk mahasiswa Program Studi Pendidikan Matematika Universitas PGRI Adi Buana Surabaya (UNIPA Surabaya). Pokok bahasan pada mata kuliah ini mengulas tentang perkembangan dan makna operasional riset, penyelesaian program linier menggunakan metode grafik; metode simplex; dan dilanjutkan dengan dualitas dan analisa sensitivtas, persoalan penugasan (assignment), persoalan transportasi, analisa jaringan (network), teori antrian, dan praktikum menggunakan software POM; LINDO; maupun QM.

Di awal perkuliahan semester gasal untuk tahun ajaran 2019/2020 ini, peneliti memberikan rancangan perkuliahan selama satu semester termasuk di dalamnya referensi sumber mata kuliah yang dapat digunakan mahasiswa serta sistem penilaian. Hal ini dimaksudkan agar mahasiswa mampu mempersiapkan diri dalam mengikuti proses belajar serta dapat menjadi kontrol bagi mahasiswa dan peneliti terhadap ketuntasan baik materi maupun evaluasi yang diberikan oleh peneliti.

Sebagian besar mahasiswa mengalami kesulitan dalam memahami dan menyelesaikan permasalahan terkait program linier dengan berbagai bentuk penyimpangan baik untuk kasus minimasi maupun maksimasi. Hingga sejauh ini, berdasarkan hasil nilai ujian tengah semester yang diperoleh sebagian besar mahasiswa masih belum mampu mencapai maksimal. Rata-rata mahasiswa mengalami kesulitan dalam menyelesaikan permasalahan program linier dengan berbagai kasus penyimpangan. Oleh sebab itu, peneliti merasa perlu untuk melakukan tindakan perbaikan pada pelaksanaan pembelajaran selanjutnya untuk mata kuliah ini.

Beberapa catatan peneliti selama memberikan perkuliahan untuk materi program linier dengan berbagai jenis kasus baik kondisi standar maupun terdapat penyimpangan dengan berbagai penyelesaian, selama perkuliahan tatap muka mahasiswa mampu menyelesaikan tugas dengan baik dan benar. Akan tetapi, apabila peneliti memberikan kesempatan untuk bertanya, tidak banyak mahasiswa yang bertanya. Dari kondisi ini peneliti berasumsi bahwa proses pembelajaran dan transfer pengetahuan berjalan dengan baik.

Akan tetapi, apabila peneliti memberikan tugas untuk diselesaikan di rumah, sebagian besar mahasiswa memiliki jawaban yang sama bahkan apabila terdapat kesalahan dalam penyelesaian soal maka sebagian besar mahasiswa memiliki kesalahan yang sama dengan jenis dan letak yang sama pula. Hal ini bertolak belakang dengan kondisi ketika pembelajaran berlangsung secara tatap muka. Bahkan, tidak jarang peneliti menemukan kejadian bahwa mahasiswa mengerjakan tugas sebelum perkuliahan dimulai. 
Kondisi ini menjadi fenomena bagi peneliti karena hasil belajar mahasiswa dengan beban 4 sks ini masih belum sesuai dengan harapan peneliti. Sebagian besar mahasiswa masih belum termotivasi belajar mandiri dan mengembangkan kemampuan penguasaan konsep dalam penyelesaian masalah terkait materi operasional riset. Mahasiswa kurang atau bahkan tidak mempersiapkan diri untuk mengikuti proses pembelajaran di kelas. Mahasiswa merasa bosan atau jenuh dengan sistem perkuliahan yang diikuti. Padahal pada tingkatan perguruan tinggi, mahasiswa diharapkan telah memiliki tanggung jawab dan kematangan diri (Afriansyah \& Dahlan, 2017) terhadap proses belajarnya.

Mahasiswa Program Studi Pendidikan Matematika UNIPA Surabaya kelas 2017-B dan 2017-C masih melakukan cara belajar yang kurang efektif, kurang memiliki maupun mengasah kemampuan cara belajar yang mencakup pemahaman kemampuan berpikir, proses berpikir, dan motivasi diri untuk mencapai tujuan belajar.

Teori kontruktivisme memandang bahwa belajar merupakan upaya aktif peserta didik untuk mengkonstruksi sendiri pengetahuannya, membandingkan informasi baru dengan pemahaman sebelumnya dan menggunakannya untuk menghasilkan pemahaman baru (Sucipto, 2017). Sementara itu, di dunia psikologi pendidikan, kemampuan proses berpikir dan motivasi diri disebut self regulated learning (SRL) (Zimmerman \& MartinezPons, 1988). Pembelajaran yang berfokus pada pembelajaran kognitif; strategi latihan, elaborasi dan organisasi telah dilakukan oleh (Pintrich, 1999; Mahmoodi, Kalantari, \& Ghaslani, 2014; Rienties, Tempelaar, Nguyen, \& Littlejohn, 2019).

Berdasarkan pengertian di atas, dapat disimpulkan bahwa SRL merupakan bagian dari teori pembelajaran kognitif yang berkaitan erat dengan perilaku, motivasi, dan lingkungan yang dapat mempengaruhi prestasi seseorang dalam belajar. Akan tetapi, apabila mahasiswa tidak memiliki motivasi dan kemampuan untuk belajar mandiri, peneliti memberikan motivasi kembali dan meningkatkan penanaman konsep kepada mahasiswa dengan memberikan penjelasan dan pemahaman materi berikutnya (Sapilin, Adisantoso, \& Taufik, 2019). Hal ini pula disampaikan oleh Kizilcec, Pérez-Sanagustín, \& Maldonado (2017) bahwa SRL berperan penting dalam memberikan kontribusi yang besar pada proses menciptakan lingkungan belajar dan kesuksesan seseorang dalam belajar.

Studi tentang umpan balik guru dan pembelajaran SRL siswa di sekolah menengah dalam pembelajaran matematika menerangkan bahwa guru yang lebih banyak melakukan SRL selalu melakukan verifikasi, arahan, dan umpan balik bagi siswa sehingga memberikan dampak positif untuk prestasi siswa dan memiliki motivasi belajar yang lebih besar untuk belajar matematika (Guo, Lau, \& 
Wei, 2019). Pemodelan secara belajar kelompok dengan menerapkan SRL juga ditunjukkan oleh Alghamdi, Karpinski, Lepp, \& Barkley (2020) bahwa bahwa grade point average (GPA) yang diperoleh siswa melalui self-efficacy untuk belajar mandiri siswa berjenis kelamin laki-laki dan perempuan menunjukkan perbedaan yang signifikan dan hubungan antara perilaku dan GPA yang diperoleh. Siswa perempuan memiliki tingkat Self-Efficacy for Self-Regulated Learning (SESRL) yang lebih tinggi dan menghasilkan kinerja akademik yang lebih baik.

Keberhasilan serupa dalam proses pembelajaran dengan model SRL memungkinkan praktik dan interaksi yang efektif antara guru dan siswa di kelas secara aktif dan memberikan dampak secara signifikan. Hal ini ditunjukkan pada hasil penelitian yang dilakukan oleh beberapa peneliti (Sumartini, 2015; Abdullah, Ghani, Ahmad, \& Yahaya, 2015; Afriansyah, 2016; Lai \& Hwang, 2016; Loeffler, Bohner, Stumpp, Limberger, \& Gidion, 2019) yang menyatakan bahwa siswa dengan pengetahuan diri yang tinggi menunjukkan prestasi belajar yang berbeda secara signifikan karena memiliki efikasi diri dalam merencanakan dan menggunakan waktu belajar secara efektif.

Berdasarkan permasalahan yang telah diuraikan, peneliti bertujuan untuk meningkatkan kemampuan pemahaman konsep matematika yang dimiliki mahasiwa secara mandiri melalui SRL untuk mata kuliah operasional riset.

\section{Metode}

Penelitian ini merupakan penelitian tindakan kelas yang melibatkan mahasiswa Program Studi Pendidikan Matematika UNIPA Surabaya angkatan 2017-B dengan jumlah mahasiswa sebanyak 30 mahasiswa dan 2017-C sebanyak 19 mahasiswa. Penggunaan penelitian tindakan kelas pada penelitian ini karena peneliti memfokuskan pada proses pembelajaran yang bertujuan untuk melakukan perbaikan dan meningkatkan kemampuan mahasiswa dalam memahami konsep matematika terapan secara mandiri. Secara umum, penelitian tindakan kelas ini untuk meningkatkan ketuntasan belajar mahasiswa melalui perilaku dan motivasi belajar mahasiswa sehingga tingkat pemahaman mahasiswa semakin baik dalam menyelesaikan permasalahan yang berkaitan dengan pengambilan keputusan untuk permasalahan operasional riset (Fitriatien, 2016).

Pada pelaksanaan perbaikan proses pembelajaran untuk mata kuliah operasional riset ini peneliti bekerjasama dengan team teaching yang terdiri dari dari dua orang dimana peneliti sebagai pelaksana penelitian sedangkan team teaching bertindak sebagai kolabotaror selama proses pembelajaran berlangsung. Peneliti menerapkan konsep yang sama untuk kedua kelas penelitian sesuai dengan jadwal perkuliahan masing-masing kelas dikarenakan peneliti melakukan perbaikan dan peningkatan kemampuan pemahaman konsep matematika 
mahasiswa, dimana selama proses perbaikan diamati oleh satu orang kolaborator selama proses perbaikan pembelajaran berlangsung.

Desain penelitian tindakan kelas ini menggunakan model Kemmis \& $M c$ Taggart yang dikemukakan dalam (Kane et al., 2015) dengan empat tahapan pelaksanaan perbaikan. Keempat tahapan tersebut meliputi perencanaan (planning), pelaksanaan (acting), pengamatan (observing), dan refleksi (reflecting). Proses perbaikan dengan empat tahapan tersebut dilakukan berulang hingga tujuan penelitian tercapai (lihat gambar 1).

Pada tahapan perencanaan untuk penelitian untuk perbaikan kelas ini, peneliti mempersiapkan materi; latihan soal di kelas; maupun tugas mandiri sesuai dengan silabus dan kontrak perkuliahan. Selanjutnya pada proses pelaksanaan peneliti membagi mahasiswa menjadi beberapa kelompok, dimana setiap mahasiswa harus mampu bertanggungjawab dan menjelaskan kepada teman kelas apabila peneliti

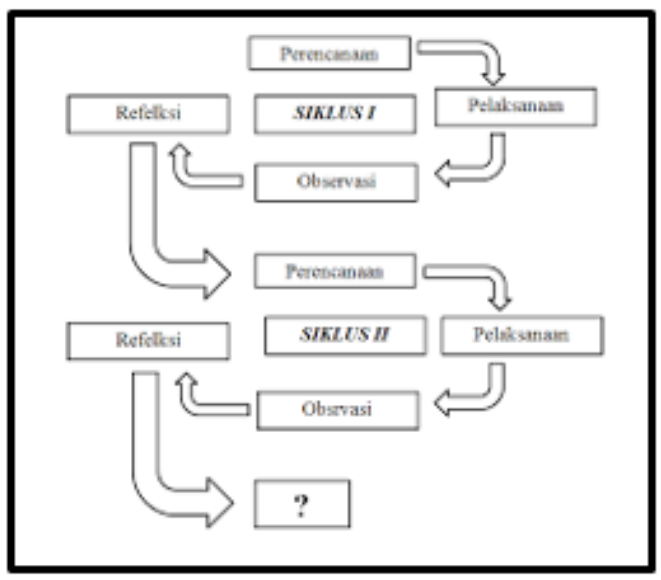

Gambar 1. Alur Penelitian Tindakan Kelas Menggunakan model Kemmis \& Mc Taggart. meminta untuk sharing pengetahuan konsep dan penyelesaian soal latihan. Peneliti memilih mahasiswa untuk berbagi dengan teman kelas secara acak. Untuk seluruh kegiatan dan proses aktivitas belajar mahasiswa diamati oleh kolaborator yang berperan sebagai kolaborator untuk mengamati kegiatan pembelajaran menggunakan lembar pengamatan aktivitas serta motivasi mahasiswa dalam belajar. Selain mengamati aktivitas dan proses belajar mahasiswa, kolaborator juga mengamati peneliti untuk melihat kesesuaian pemaparan materi perkuliahan dan situasi proses pembelajaran.

Selama proses perbaikan dengan menerapkan SRL ini dengan membagi kelas menjadi 3 sampai 5 kelompok, dimana setiap kelompok memiliki ketua kelompok yang bertugas menjadi tutor sebaya. Sebelum berbagi dengan teman anggotanya, setiap ketua kelompok ini berdiskusi terlebih dahulu dengan sesama ketua kelompok yang lain dimana peneliti sebagai fasilitator. Kemudian setelah memperoleh pemahaman dan hasil yang sama, ketua kelompok kembali ke kelompoknya masing-masing untuk berbagi materi dan pembahasan dengan anggotanya. Setelah seluruh anggota dipastikan sudah mengerti dan memahami konsep yang dipelajari dalam kelompok kecil, kemudian secara acak peneliti memanggil anggota kelompok untuk mempresentasikan hasil yang diperolehnya. Sedangkan untuk kelompok 
lain menyimak dan mengoreksi hasil pemaparannya. Dipertemuan selanjutnya, peneliti mengacak kembali posisi setiap ketua kelompok untuk bertukat pikiran di kelompok lain. Jadi yang selalu berpindah dan memperoleh anggota kelompok baru adalah ketua kelompoknya.

Selanjutnya peneliti melakukan refleksi terhadap temuan yang ada selama kegiatan pembelajaran berlangsung. Kegiatan penelitian ini dilaksanakan mulai 21 Oktober hingga 15 November 2019 dengan beberapa kali perbaikan sesuai dengan target yang dicapai. Capaian target proses perbaikan ini berhasil dan berakhir setelah melalui tiga kali proses perbaikan dengan ketuntasan klasikal total lebih dari 75\% dan keberhasilan pemahaman konsep dilihat dari perhitungan persentase nilai yang diperoleh mahasiswa dengan persamaan 1.

$$
P=\frac{n}{N} x 100 \%
$$

Dimana:

P: persentase mahasiswa yang tuntas $n$ : banyaknya mahasiswa yang tuntas $N$ : banyaknya mahasiswa

Instrumen penelitian yang peneliti gunakan dalam pelaksanaan proses perbaikan ini meliputi lembar pengamatan aktivitas belajar mahasiswa dan tes untuk mengetahui capaian pembelajaran akir untuk mata kuliah operasional riset. Selain itu, dokumen nilai tes dan catatan di lapangan digunakan peneliti sebagai bahan acuan untuk melakukan refleksi pada setiap proses perbaikan.

\section{Hasil dan Pembahasan}

Pelaksanaan kegiatan perbaikan proses pembelajaran pada penelitian ini merupakan salah satu alternatif cara untuk memacu mahasiswa Program Studi Pendidikan Matematika UNIPA Surabaya angkatan 2017-B dan 2017-C untuk menumbuhkan keingingan belajar dan mengasah kemampuan diri secara mandiri. Proses perbaikan dilengkapi dengan pemberian latihan tugas secara mandiri dan kelompok berdasarkan buku referensi mata kuliah operasional riset yang digunakan pada semester gasal tahun ajaran 2019/2020 ini.

Pelaksanaan perbaikan ini secara bertahap memberikan gambaran hasil yang baik terkait perubahan kebiasaan mahasiswa dalam melaksanakan kegiatan pembelajaran. Secara bertahap, mahasiswa mampu menyelesaikan permasalahan kasus operasional riset dengan kasus pernyimpangan untuk program linier dengan berbagai metode penyelesaian sesuai pemahaman mahasiswa. Proses penyelesaian yang disajikan juga telah sesuai dengan konsep dan proses algoritma yang secara sistematis, dari permasalahan biasa hingga permasalahan kompleks dengan berbagai penyimpangan dari kasus permalasahan yang diberikan oleh peneliti.

Melalui SRL yang didesain secara kelompok ini, kesan dan dampak yang diperoleh mahasiswa diantaranya adalah mampu menumbuhkan rasa percaya diri dalam mengerjakan secara mandiri dan 
mampu mempertanggungjawabkan di depan kelas untuk berbagi pendapat dengan mahasiswa lain, serta mampu berdiskusi secara terbuka apabila terdapat perbedaan hasil baik tugas mandiri maupun tugas secara berkelompok. Perubahan mahasiswa dalam memiliki rasa mampu untuk menyelesaiakan permasalahan dari soal dapat diselesaikan dengan baik dan muncul keinginan untuk selalu berusaha guna menyelesaikan hingga memperoleh jawaban yang optimum pada kasus operasional riset. Kondisi ini mulai terlihat pada proses perbaikan yang kedua untuk masingmasing kelas perbaikan, sedangkan untuk proses perbaikan yang ketiga terlihat pada peningkatan nilai tes yang diperoleh mahasiswa yang semakin baik terlihat pada pada Tabel 1 dan Tabel 2 .

Proses perbaikan melalui SRL ini dilandasi oleh pemikiran (Broadbent \& Poon, 2015) yang menyatakan bahwa melalui pembelajaran yang menggunakan SRL membutuhkan tingkat percaya diri dan ketekunan dalam mempelajari materi dai berbagai sumber belajar. Hal ini dikemukan pula oleh (Jansen, van Leeuwen, Janssen, Jak, \& Kester, 2019).

Pada proses perbaikan yang pertama, mahasiswa terlihat antusias dengan pembelajaran yang dilaksanakan. Akan tetapi, ketika proses berlanjut, terlihat kondisi mahasiswa 2017-C jenuh dengan berbagai tugas yang diberikan baik secara mandiri maupun berkelompok. Kondisi ini terjadi diantaranya karena mahasiswa
2017-C sebagian besar telah bekerja, sehingga ketika mengikuti perkuliahan kelas malam yang dimulai pukul 17.00 WIB, kondisi mahasiswa sudah lelah dan tingkat konsentrasi tidak sebaik dengan mahasiswa 2017-B yang merupakan

Tabel 1.

Analisis Hasil Tes untuk Setiap Perbaikan (Kelas 2017-B)

\begin{tabular}{lccc}
\hline Keterangan & $\begin{array}{c}\text { Perbaikan } \\
\text { 1 }\end{array}$ & $\begin{array}{c}\text { Perbaikan } \\
\text { 2 }\end{array}$ & $\begin{array}{c}\text { Perbaikan } \\
\text { 3 }\end{array}$ \\
\hline $\begin{array}{l}\text { Jumlah } \\
\text { Mahasiswa } \\
\text { yang } \\
\text { Tuntas }\end{array}$ & 13 & 19 & 26 \\
\hline $\begin{array}{l}\text { Jumlah } \\
\text { Mahasiswa } \\
\text { yang Tidak } \\
\text { Tuntas }\end{array}$ & 17 & 11 & 4 \\
\hline $\begin{array}{l}\text { Persentase } \\
\text { Tuntas (\%) }\end{array}$ & 43,33 & 63,33 & 86,67 \\
\hline $\begin{array}{l}\text { Persentase } \\
\text { Tidak }\end{array}$ & 56,67 & 36,67 & 13,33 \\
Tuntas (\%) & & & \\
\hline $\begin{array}{l}\text { Rata-rata } \\
\text { Nilai }\end{array}$ & 71,26 & 77,81 & 88,45 \\
\hline
\end{tabular}

Tabel 2.

Analisis Hasil Tes untuk Setiap Perbaikan (Kelas 2017-C)

\begin{tabular}{lccc}
\hline Keterangan & $\begin{array}{c}\text { Perbaikan } \\
1\end{array}$ & $\begin{array}{c}\text { Perbaikan } \\
\text { 2 }\end{array}$ & $\begin{array}{c}\text { Perbaikan } \\
3\end{array}$ \\
\hline $\begin{array}{l}\text { Jumlah } \\
\text { Mahasiswa } \\
\text { yang }\end{array}$ & 7 & 11 & 15 \\
Tuntas & & & \\
\hline $\begin{array}{l}\text { Jumlah } \\
\text { Mahasiswa } \\
\text { yang Tidak } \\
\text { Tuntas }\end{array}$ & 12 & 8 & 4 \\
\hline $\begin{array}{l}\text { Persentase } \\
\text { Tuntas (\%) }\end{array}$ & 36,84 & 57,90 & 78,95 \\
\hline $\begin{array}{l}\text { Persentase } \\
\text { Tidak } \\
\text { Tuntas (\%) }\end{array}$ & 63,16 & 42,11 & 21,05 \\
\hline $\begin{array}{l}\text { Rata-rata } \\
\text { Nilai }\end{array}$ & 69,32 & 75,06 & 81,63 \\
\hline
\end{tabular}


mahasiswa regular. Hal ini dapat terlihat dari adanya perbedaan rata-rata nilai yang diperoleh mahasiswa setelah proses pelaksanaan perbaikan kedua. Akan tetapi, pada tahap perbaikan ketiga, perolehan rata-rata nilai tugas mahasiswa 2017-C mengalami kenaikan kembali, sedangkan untuk mahasiswa 2017-B di setiap proses perbaikan selalu memperoleh progress yang baik dan meningkat. Berikut akan disajikan Gambar 2 yang menyatakan kondisi rata-rata nilai yang diperoleh mahasiswa angkatan 2017-B dan 2017-C setelah dilaksanakan perbaikan.

Proses perbaikan ini menitikberatkan pada kondisi mahasiswa yang kurang mengoptimalkan kualitas belajar mandiri sehingga target untuk menyelesaikan tugas mandiri dianggap menjadi beban dan bersifat menjenuhkan bagi mahasiswa yang tidak terbiasa.

Untuk tugas yang diberikan secara berkelompok, dapat dilihat melalui perkembangan aktivitas mahasiswa dalam mengikuti proses pembelajaran semakin

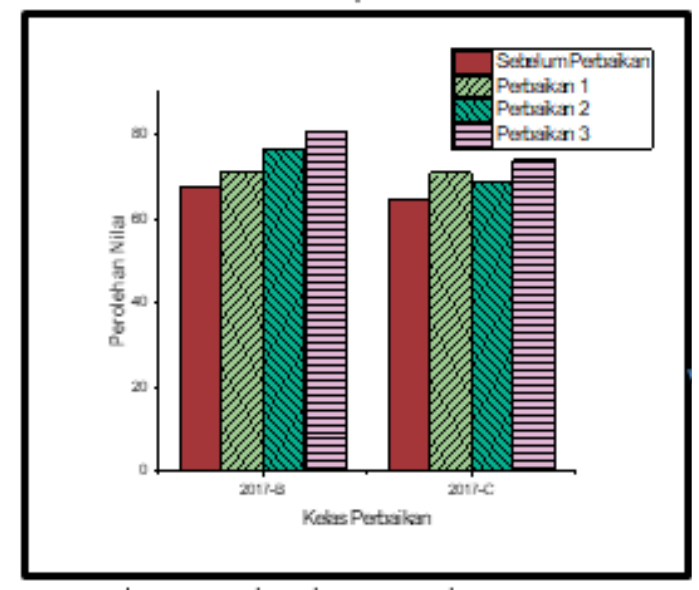

Gambar 2. Perkembangan Nilai Rata-Rata Tugas Mandiri Selama Tiga Kali Perbaikan. aktif, hal ini terlihat dari aktivitas belajar dan tanggungjawab secara kelompok dalam menyelesaikan proyek tugas dengan menyelesaikan rancangan tugas kelompok yang mulai terlihat pada proses perbaikan kedua. Hasil perbaikan dan perkembangan untuk aktivitas belajar mahasiswa disajikan pada Gambar 3.

Melalui model SRL ini mahasiswa mampu melakukan evaluasi secara mandiri terhadap kemampuan diri dalam menjelaskan kembali di depan kelas mulai terlihat pada proses perbaikan kedua, sedangkan untuk penguasaan konsep dan pemahaman materi dengan melakukan drill latihan soal dan memperbaiki waktu belajar secara mandiri sejak perbaikan ketiga sehingga tidak selalu bergantung pada dosen di dalam kelas. Oleh sebab itu, SRL merupakan salah satu alternatif sebagai upaya perbaikan pada proses pembelajaran untuk mata kuliah operasional riset untuk 2017-B dan 2017C.

Dari hasil pengamatan, didapatkan informasi bahwa setelah mahasiswa

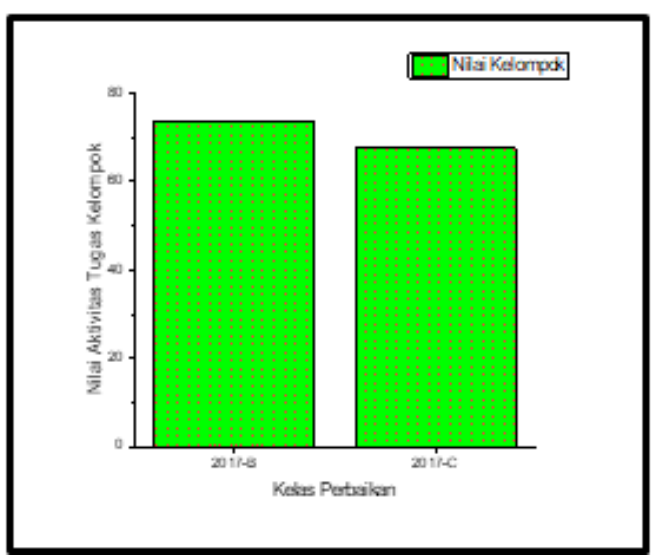

Gambar 3. Aktivitas Perkembangan Nilai RataRata Tugas Mandiri Setelah Tiga Kali Perbaikan. 
menerima pembelajaran dari dosen selama di kelas dengan ditambah melalui proses belajar mandiri, mahasiswa merasa memiliki kemampuan yang lebih baik dibandingkan sebelum dilakukan proses perbaikan melalui SRL. Kemampuan aktivitas belajar mahasiswa setelah dilakukan perbaikan sebanyak tiga kali perbaikan yang dilaksanakan peneliti yang berkolaborasi dengan team teaching melalui proses pembelajaran SRL disajikan pada Gambar 4.

Berdasarkan proses pelaksanaan pembelajaran yang dilakukan pada kedua kelas (2017-B dan 2017-C) melalui SRL, memberikan dampak perubahan yang positif bagi mahasiswa untuk tingkat percaya diri dalam mengutarakan pendapat dan berbagi pengetahuan baik dengan dalam satu kelompok maupun dengan teman satu kelas.

Hasil proses pelaksanaan pembelajaraan perbaikan ini sejalan dengan hasil penelitian yang dilakukan oleh Indrawati $F$ dan Hartati $L$ yang menjelaskan terkait penguasaan dasar

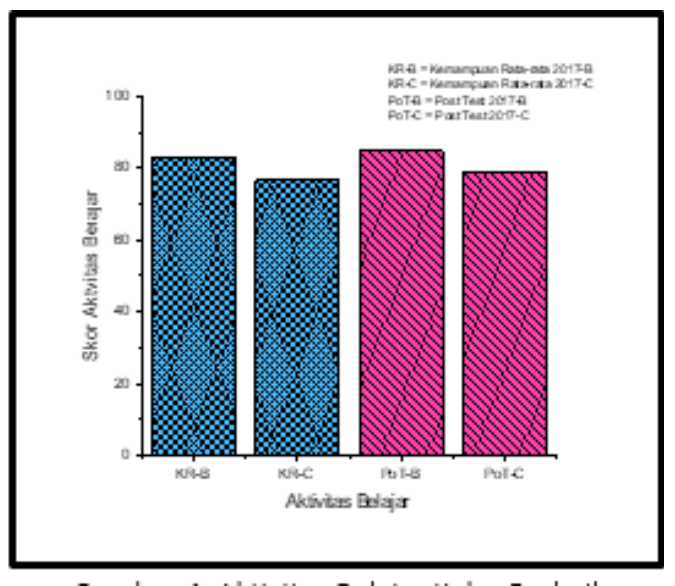

Gambar 4. Akttivitas Belaiar Kelas Pērbaikan. matematika dan persepsi mahasiswa dalam kemampuan pemahaman konsep mata kuliah kalkulus 1. Artinya bahwa salah satu faktor yang memberi peran dalam mempelajari mata kuliah kalkulas 1 adalah persepsi mahasiswa terhadap materi mata kuliah itu sendiri (Indrawati \& Hartati, 2017). Selain itu usaha yang dilakukan oleh Sapilin dkk dalam melakukan proses perbaikan pembelajaran juga menghasilkan kesimpulan bahwa untuk mencapai pemahaman konsep matematika pada peserta didik melalui model pembelajaran discovery learning memberikan dampak yang baik terhadap kemampuan peserta didik itu sendiri (Sapilin dkk., 2019). Selain itu, penelitian terdahulu memberikan gambaran bahwa usaha perbaikan yang dilakukan baik oleh guru atau dosen dalam proses pembelajaran guna memberikan pemahaman konsep matematika memberikan dampak yang baik (Ridia \& Afriansyah, 2019) guna pengetahuan dan penanaman konsep bagi setiap pembelajar (Priyambodo, 2016) dan rasa percaya diri setiap individu pembelajar (Sritresna, 2017). Hal ini sejalan dengan hasil penelitian yang dilakukan oleh peneliti melalui SRL dengan memberikan hasil terdapat hasil yang baik untuk setiap proses perbaikan pembelajaran.

\section{Penutup}

Dari hasil proses perbaikan pembelajaran melalui SRL ini mampu secara efektif dalam pembelajaran mata 
kuliah operasional dengan segala bentuk kasus normal maupun penyimpangan untuk materi program linier yang diselesaikan dengan metode-metode pengambilan keputusan pada operasional riset.

Pembelajaran melalui SRL ini cukup efektif untuk meningkatkan kemampuan pemahaman konsep belajar mahasiswa secara mandiri, hal ini ditandadi dengan adanya perubahan nilai yang diperoleh oleh mahasiswa untuk jenis soal yang sejenis dengan soal ujian tengah semester dan memiliki inisiatif untuk memilih baik metode penyelesaian tugas maupun pola belajar yang diterapkan mahasiswa secara individu maupun diskusi kelompok.

Model pembelajaran ini memberikan kesempatan kepada mahasiswa untuk belajar aktif dengan melakukan kontrol diri sendiri dan motivasi diri selama proses pembelajaran berlangsung, menumbuhkan rasa percaya diri sehingga mampu meningkatkan hasil belajar mahasiswa melalui pemahaman konsep di setiap materi operasional riset dengan memilih cara dan metode penyelesaian setiap permasalahan atau kasus yang ada.

Dengan adanya keberagaman latar belakang pendidikan, karakteristik dan ekonomi keluarga di lingkungan mahasiswa Program Studi Pendidikan Matematika UNIPA Surabaya seperti saat ini, maka untuk kebutuhan belajar dan proses pembelajaran baik selama di dalam maupun di luar kampus, model pembelajaran melalui SRL ini dapat menjadi alternatif yang perlu dikembangkan oleh peneliti selaku staf pengajar di institusi ini untuk mata kuliah operasional riset maupun mata kuliah lain yang peneliti ampu. Selain itu, dapat pula dikembangkan menjadi lebih baik apabila dilakukan kolaborasi menggunakan jenis model pembelajaran yang lebih variatif.

\section{Daftar Pustaka}

Afriansyah, E. A. (2016). Enhancing Mathematical Problem Posing via Realistic Approach. International Seminar on Mathematics, Science, and Computer Science Education MSCEIS.

Afriansyah, E. A., \& Dahlan, J. A. (2017). Design Research in Fraction for Prospective Teachers. The 5th SEA-DR (South East Asia Development Research) International Conference 2017 (SEADRIC 2017).

Abdullah, M. F. N. L., Ghani, S. A., Ahmad, C. N. C., \& Yahaya, A. (2015). Students' Discourse in Learning Mathematics with Self-Regulating Strategies. Procedia - Social and Behavioral Sciences. DOI: https://doi.org/10.1016/j.sbspro.201 5.04.270

Alghamdi, A., Karpinski, A. C., Lepp, A., \& Barkley, J. (2020). Online and face-toface classroom multitasking and academic performance: Moderated mediation with self-efficacy for selfregulated learning and gender. Computers in Human Behavior. DOI: https://doi.org/10.1016/j.chb.2019.0 8.018

Broadbent, J., \& Poon, W. L. (2015). Selfregulated learning strategies \& 
academic achievement in online higher education learning environments: A systematic review. Internet and Higher Education. DOI: https://doi.org/10.1016/j.iheduc.201 5.04 .007

Fitriatien, S. R. (2016). Metode Transportasi Ssebagai Solusi Alternatif dalam Pengambilan Keputusan pada Operasional Riset. Seminar Nasional "Menyiapkan Pendidikan Matematika Dalam Menghadapi MEA"", 43-50. DOI: https://doi.org/10.17605/OSF.IO/X95 JP | ARK c7605/osf.io/x95jp

Guo, W., Lau, K. L., \& Wei, J. (2019). Teacher feedback and students' selfregulated learning in mathematics: $A$ comparison between a high-achieving and a low-achieving secondary schools. Studies in Educational Evaluation. DOI: https://doi.org/10.1016/j.stueduc.20 19.07.001

Indrawati, F., \& Hartati, L. (2017). Peran Penguasaan Dasar Matematika dan Persepsi Mahasiswa Terhadap Kemampuan Pemahaman Konsep Mata Kuliah Kalkulus I. Formatif: Jurnal Ilmiah Pendidikan MIPA. DOI: https://doi.org/10.30998/formatif.v7i 2.2226

Jansen, R. S., van Leeuwen, A., Janssen, J., Jak, S., \& Kester, L. (2019). Selfregulated learning partially mediates the effect of self-regulated learning interventions on achievement in higher education: A meta-analysis. Educational Research Review. DOI: https://doi.org/10.1016/j.edurev.201 9.100292

Kane, R. G., Chimwayange, C., Sigler, E., Li,
D. W., Burns, A., Kurtoğlu-Hooton, N., ... Abraham, A. (2015). Action Research. Action Research. DOI: https://doi.org/10.1177/1476750307 083716

Kizilcec, R. F., Pérez-Sanagustín, M., \& Maldonado, J. J. (2017). Selfregulated learning strategies predict learner behavior and goal attainment in Massive Open Online Courses. Computers and Education. DOI: https://doi.org/10.1016/j.compedu.2 016.10 .001

Lai, C. L., \& Hwang, G. J. (2016). A selfregulated flipped classroom approach to improving students' learning performance in a mathematics course. Computers and Education. DOI:

https://doi.org/10.1016/j.compedu.2 016.05.006

Loeffler, S. N., Bohner, A., Stumpp, J., Limberger, M. F., \& Gidion, G. (2019). Investigating and fostering selfregulated learning in higher education using interactive ambulatory assessment. Learning and Individual Differences. DOI: https://doi.org/10.1016/j.lindif.2019. 03.006

Mahmoodi, M. H., Kalantari, B., \& Ghaslani, R. (2014). Self-Regulated Learning (SRL), Motivation and Language Achievement of Iranian EFL Learners. Procedia - Social and Behavioral Sciences. DOI: https://doi.org/10.1016/j.sbspro.201 4.03.517

Pintrich, P. R. (1999). The role of motivation in promoting and sustaining self-regulated learning. International Journal of Educational 
Research.

https://doi.org/10.1016/S0883-

0355(99)00015-4

Priyambodo, S. (2016). Peningkatan Kemampuan Pemahaman Konsep Matematis Siswa dengan Metode Pembelajaran Personalized System of Instruction. Mosharafa: Jurnal Pendidikan Matematika, 5(1), 10-17.

Ridia, N. S., \& Afriansyah, E. A. (2019). Perbandingan Kemampuan Pemahaman Matematis Siswa melalui Auditory Intellectualy Repetition dan Student Teams Achievement Division. Mosharafa: Jurnal Pendidikan Matematika, 8(3), 515-526. DOI: https://doi.org/10.31980/mosha rafa.v8i3.509

Rienties, B., Tempelaar, D., Nguyen, Q., \& Littlejohn, A. (2019). Unpacking the intertemporal impact of selfregulation in a blended mathematics environment. Computers in Human Behavior.

https://doi.org/10.1016/j.chb.2019.0 7.007

Sapilin, S., Adisantoso, P., \& Taufik, M. (2019). Peningkatan Pemahaman Konsep Peserta Didik dengan Model Discovery Learning pada Materi Fungsi Invers. Mosharafa: Jurnal Pendidikan Matematika, 8(2), 285296.

DOI: https://doi.org/10.31980/mosha rafa.v8i2.476

Sritresna, T. (2017). Meningkatkan Kemampuan Komunikasi Matematis dan Self-Confidence Siswa Melalui Model Pembelajaran Cycle 7E. Mosharafa: Jurnal Pendidikan Matematika, 6(3), 419-430. DOI: https://doi.org/10.31980/mosharafa. v6i3.330

Sucipto. (2017). Peningkatan Self Regulated Learning Mahasiswa Di Era Digital. Jurnal Ilmiah : Soulmath.

Sumartini, T. S. (2015). Mengembangkan Self Concept Siswa Melalui Model Pembelajaran Concept Attainment. Mosharafa: Jurnal Pendidikan Matematika, 4(2), 48-57.

Zimmerman, B. J., \& Martinez-Pons, $M$. (1988). Construct Validation of a Strategy Model of Student SelfRegulated Learning. Journal of Educational Psychology. https://doi.org/10.1037/00220663.80.3.284

\section{Riwayat Hidup PenUlis}

\section{Sri Rahmawati Fitriatien, S.Pd., M.Si.}

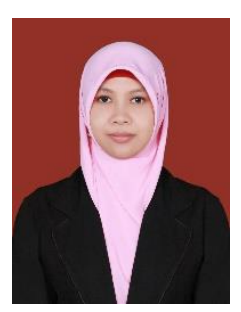

Lahir di Sidoarjo, 26 Juni 1987. Staf pengajar di Universitas PGRI Adi Buana Surabaya. Studi S1 Pendidikan Matematika di Universitas PGRI Adi Buana, Surabaya, lulus tahun 2011; S2 Matematika di Institut Teknologi Sepuluh Nopember, Surabaya, lulus tahun 2015.

\section{Ninik Mutianingsih, S.Pd., M.Si.}

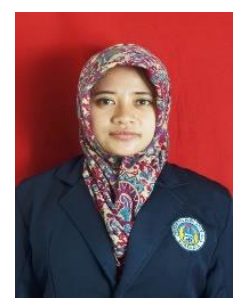

Lahir di Mojokerto, 27 Maret 1989. Staf pengajar di Universitas PGRI Adi Buana Surabaya. Studi S1 Pendidikan Matematika di Universitas PGRI Adi Buana, Surabaya, lulus tahun 2011; S2 Matematika di Institut Teknologi Sepuluh Nopember, Surabaya, lulus tahun 2015. 